\title{
Response of the common bean to liquid fertilizer and Rhizobium tropici inoculation
}

\section{Resposta do feijoeiro comum a fertilizante líquido e inoculação com Rhizobium tropici}

\author{
José Geraldo da Silva ${ }^{1}$; Enderson Petrônio de Brito Ferreira ${ }^{1 *}$; Virgínia Damin²; \\ Adriano Stephan Nascente ${ }^{1}$
}

\section{Highlights:}

Synergism between liquid fertilizer and biological nitrogen fixation.

Liquid fertilizer applied at $6 \mathrm{~cm}$ improves crop management.

Increased grain yield in inoculated common bean.

\begin{abstract}
The common bean production system is majorly based on the use of granular fertilizers to provide nutrients for the crop. Studies on the use of liquid fertilization at an appropriated depth and, seed inoculation with Rhizobium tropici can provide significant increases in the grain yield of the common bean. The objective of this study was to determine the growth and productivity of common bean as affected by N-P formulations, application depths and the inoculation with $R$. tropici. Field experiments were carried out in 2015 and 2016 cropping years using a complete block design, in a $2 \times 2 \times 2$ factorial arrangement, with four replicates. The treatments involved the combination of N-P formulation (granular and liquid), two application depths of the N-P formulation $(6$ and $12 \mathrm{~cm})$ and with or without rhizobia inoculant. The plant density (PD), number of pods (NP), number of grains (NG), mass of 100 grains (M100) and grain yield $(\mathrm{GY})$ were determined. The granular and liquid N-P formulations provided similar results for PD, NP, NG, and GY of common bean. Similarly, the application depth of the N-P formulations did not affect GY. Inoculation of the seed with $R$. tropici stimulated NP and NG, increasing GY. Growth and productivity parameters were equally affected by the type of formulation and application depth; however, GY was greater with rhizobial inoculant. Thus, the liquid N-P formulation, applied at $6 \mathrm{~cm}$ depth, associated with rhizobial inoculant can improve the crop management providing better control of application uniformity, minimal soil mobilization, less fuel consumption, and increased grain yield.

Key words: Application depth. Cerrado. Phaseolus vulgaris. Rhizobia.
\end{abstract}

\section{Resumo}

O sistema de produção do feijoeiro comum baseia-se principalmente no uso de fertilizantes granulares para fornecer nutrientes para a cultura. Estudos sobre o uso de adubação líquida em profundidade apropriada e a inoculação de sementes com Rhizobium tropici podem proporcionar aumentos significativos no rendimento de grãos do feijoeiro comum. O objetivo deste estudo foi determinar o

${ }^{1}$ Pesquisadores, Empresa Brasileira de Pesquisa Agropecuária, EMBRAPA Arroz e Feijão, Santo Antônio de Goiás, GO, Brasil. E-mail: josegeraldo.silva@embrapa.br; enderson.ferreira@embrapa.br; adriano.nascente@embrapa.br

2 Prof $^{a}$ Dra $^{\mathrm{a}}$, Departamento de Agronomia, Programa de Pós-Graduação em Agronomia, Universidade Federal de Goiás, UFG, Goiânia, GO, Brasil. E-mail: virginadamin@gmail.com

* Author for correspondence 
crescimento e a produtividade do feijoeiro afetado pelas formulações de N-P, profundidade de aplicação e inoculação com rizóbio. Os experimentos foram conduzidos nos anos agrícolas de 2015 e 2016 . O delineamento experimental foi o de blocos completos, em esquema fatorial 2x2x2, com quatro repetições. Os tratamentos envolveram a combinação da formulação N-P (sólida e líquida), duas profundidades de aplicação da formulação N-P (6 e $12 \mathrm{~cm}$ ) e com ou sem inoculante (Rhizobium tropici). A densidade de plantas (DP), número de vagens (NV), número de grãos (NG), massa de 100 grãos (M100) e produção de grãos (PG) foram determinados. As formulações de N-P sólida e líquida forneceram resultados semelhantes para DP, NV, NG e PG do feijão comum. Da mesma forma, a profundidade de aplicação das formulações de N-P não afetou a PG. A inoculação da semente com rizóbio estimulou o NV e $\mathrm{NG}$, aumentando a PG. Os parâmetros de crescimento e produtividade foram igualmente afetados pelo tipo de formulação e profundidade de aplicação; contudo, a PG foi maior com a inoculação. Assim, a formulação N-P líquida, aplicada a $6 \mathrm{~cm}$ de profundidade, associada ao inoculante, pode melhorar o manejo do feijoeiro comum, proporcionando melhor controle da uniformidade da aplicação, menor revolvimento do solo, menor consumo de combustível e maior produção de grãos.

Palavras-chave: Cerrado. Phaseolus vulgaris. Profundidade de aplicação.

\section{Introduction}

The common bean (Phaseolus vulgaris L.) has great economic importance for Brazil. The cultivated area in the 2018/2019 harvest was about 3.14 million hectares, resulting in grain production of 3.06 million tons (Compania Nacional de Abastecimento [CONAB], 2019). The common bean is grown in three cropping seasons and, despite its importance, advanced technology is poorly used on the crop management, mainly in the first and second cropping seasons, resulting in productivity level ranging from 877 to $1,088 \mathrm{~kg} \mathrm{ha}^{-1}$ (CONAB, 2019). The third cropping season is characterized as the most advanced technologically (Nascente, Kluthcouski, Crusciol, Cobucci, \& Oliveira, 2012), with an average yield of $2,631 \mathrm{~kg} \mathrm{ha}^{-1}$ in the CenterSouth region in the 2018/2019 harvest. Even in the third cropping season, technological adjustments are needed to improve grain yield of the common bean. Some aspects related to the plant nutrition can be improved, such as the fertilization management (Melém, Brito, Fonseca, Fonseca, \& Aguiar, 2011) and the use of seed inoculation aiming at biological nitrogen fixation-BNF (Brito, Muraoka, \& Silva, 2011).

The fertilization management of the common bean in Brazil is based on the use of conventional inputs, such as granulated fertilizers, which demand great logistics for their use. Notably, instead of using
BNF, the nitrogen fertilization of the common bean is based on the use of $\mathrm{N}$-fertilizers, which have high prices and risks of environmental impact (Siqueira, Piccoli, Costa, Cerri, \& Bernoux, 2011; Bortolotto et al., 2012; Rodrigues, Mello, Conceição, Souza, \& Silva, 2017). Currently, common bean producers are looking for inputs and technologies that make easier the crop management and also reduce environmental impacts and production costs.

Cutting edge technologies are always on the focus of the common bean farmers. Thus, liquid fertilizers are increasingly gaining space in the market. Its use is spreading in Brazil and attracting the attention of the largest companies of the agribusiness. Liquid fertilizers can increase the efficiency of nutrients use due to some factors, such as easier handling, better distribution in the soil and greater agronomic efficiency through the use of combined sources (Desenvolvimento Rural, 2020). However, there are few scientific studies stating its effectiveness. Thus, more experimental data are needed to provide information to technicians and farmers on the use of this technology.

Another factor growing in importance is the seed inoculation with Rhizobium tropici before common bean sowing. The use of $R$. tropici in the common bean can provide significant increases in grain yield, besides reducing the production cost by reducing the need for $\mathrm{N}$-fertilization. According to 
A. P. Oliveira, Silva, Arruda, Nascimento and Alves (2003), the common bean requires the application of a certain amount of nitrogen until the nodulation is fully established. Brito et al. (2011) stated that this dose should provide good plant development, but not harm nodulation. In this sense, it is necessary to know the cultivar and the development conditions of the culture to define the appropriate nitrogen dose that does not affect the BNF. According to Brito et al. (2011), common beans need a starting dose of $40 \mathrm{~kg} \mathrm{ha}^{-1}$ of $\mathrm{N}$, combined with the seed inoculation with $R$. tropici, to obtain economically acceptable productivity.

Thus, agronomic techniques such as the use of liquid fertilization at the sowing time and seed inoculation with $R$. tropici can provide significant increases in the grain yield of the common bean. However, published works combining these technologies are rare in literature. Thus, the objective of this study was to determine the effect of liquid and granular formulations of N-P fertilizer, applied at different depths and the seed inoculation with $R$. tropici on the agronomical performance of the common bean, cultivated in the Cerrado conditions.

\section{Material and Methods}

Two field experiments were conducted in two consective cropping years (2015 and 2016) at Embrapa Arroz e Feijão, located in the municipality of Santo Antônio de Goiás, GO, under the geographical coordinates $16^{\circ} 28^{\prime} 00^{\prime \prime} \mathrm{S}$ and $49^{\circ} 17^{\prime} 00^{\prime \prime} \mathrm{W}$, and $823 \mathrm{~m}$ above sea level. According to Köppen's classification the climate of the region is classified as Aw, tropical savanna (Alvares, Stape, Sentelhas, Gonçalves, \& Sparovek, 2013), with a dry season from May to September (autumn/winter) and rainy season from October to April (spring/ summer). The average annual rainfall is between 1,500 to $1,700 \mathrm{~mm}$. The average annual temperature is $22.7^{\circ} \mathrm{C}$, varying from $14.2^{\circ} \mathrm{C}$ to $34.8^{\circ} \mathrm{C}$.

The soil in the experimental areas was classified as a Ferralsol. Before the installation of the experiments, 10 soil subsamples $(0-20 \mathrm{~cm})$ were taken to evaluate soil chemical properties. Chemical analyzes were performed according to the methodology proposed by Donagena, Campo, Calderano, Teixeira and Viana (2011). Before being analyzed, soil samples were dried $\left(60{ }^{\circ} \mathrm{C}\right.$ for 48 h) and sieved $(2 \mathrm{~mm})$. Soil $\mathrm{pH}$ was determined in $0.01 \mathrm{M} \mathrm{CaCl}_{2}$ (1:2.5; soil/solution), after agitation for $1 \mathrm{~h}$. Exchangeable $\mathrm{Ca}$ and $\mathrm{Mg}$ were determined in the extract obtained with $1 \mathrm{~mol} \mathrm{~L}^{-1} \mathrm{KCl}(1: 10$; soil/solution) after agitation for $10 \mathrm{~min}$. $\mathrm{P}$ and $\mathrm{K}$ contents were evaluated in the Mehlich-1 $(0.05 \mathrm{~mol}$ $\left.\mathrm{L}^{-1} \mathrm{HCl}+0.0125 \mathrm{~mol} \mathrm{~L}^{-1} \mathrm{H}_{2} \mathrm{SO}_{4}\right)$ extract (1:10; soil/ solution) after agitation for $10 \mathrm{~min}$. Concentrations of $\mathrm{Ca}$ and $\mathrm{Mg}$ were determined in an atomic absorption spectrophotometer, $\mathrm{K}$ in a flame photometer and $\mathrm{P}$ by colorimetry, using the molybdenum-blue method and ascorbic acid as reducing agent. Organic matter was determined by Walkley \& Black method. Soil characteristics before sowing at each site are shown in Table 1. (Table 1)

Table 1

Soil chemical attributes and native rhizobial polulation of the experimental areas in the 0-0.20 $\mathrm{m}$ depth layer before sowing

\begin{tabular}{|c|c|c|c|c|c|c|c|}
\hline \multirow{2}{*}{ Cropping years } & pH & $\mathrm{Ca}$ & Mg & $\mathbf{P}$ & $\mathbf{K}$ & \multirow{2}{*}{$\frac{\text { SOM }^{a}}{\mathrm{~g} \mathrm{~kg}^{-1}}$} & \multirow{2}{*}{$\begin{array}{l}\text { Rhizobial cells } \\
\left(\mathrm{CFU}^{\mathrm{b}} \mathrm{g}^{-1} \text { soil }\right)\end{array}$} \\
\hline & in $\mathrm{H}_{2} \mathrm{O}$ & \multicolumn{2}{|c|}{$\mathrm{mmol}_{\mathrm{c}} \mathrm{dm}^{-3}$} & \multicolumn{2}{|c|}{$\mathrm{mg} \mathrm{kg}^{-1}$} & & \\
\hline 2015 & 5.7 & 16.7 & 13.4 & 18.1 & 125 & 26.6 & $2.77 \times 10^{4}$ \\
\hline 2016 & 5.4 & 26.0 & 10.1 & 12.4 & 92 & 34.3 & $2.60 \times 10^{4}$ \\
\hline
\end{tabular}

a $\mathrm{SOM}=$ soil organic matter.

${ }^{\mathrm{b}} \mathrm{CFU}=$ colony forming unit, estimated by the most probable number (MPN) method (Vincent, 1970) using common bean as trap plants. 
The experiments were conducted under notillage system, with corn/soybeans as previous crops grown in the summer and common bean in the winter. In both cropping years, topdressing $\mathrm{N}$-fertilization was carried out in the phenological stage V4 of the common bean (third fully expanded trifoliolate leaf), being applied $60 \mathrm{~kg} \mathrm{ha}^{-1}$ of $\mathrm{N}$, as urea.

Field experiments were addressed to a complete block design with four replicates, in a $2 \times 2 \times 2$ factorial scheme, being the factors composed of: two N-P formulations (liquid and granular), two application depths of N-P formulations (6 and 12 $\mathrm{cm}$ ) and two seed inoculations (with and without $R$. tropici). Before sowing the seeds were inoculated with peat inoculum, containing the commercial strain SEMIA 4077 (Rhizobium tropici), using 2 doses $\mathrm{ha}^{-1}$, corresponding to $500 \mathrm{~g}$ of peat inoculum for each $50 \mathrm{~kg}$ of seeds. To facilitate the inoculum adhesion to the seeds, $300 \mathrm{~mL}$ of a $10 \%$ $\left(\mathrm{w} \mathrm{V}^{-1}\right)$ sucrose solution was used for each $50 \mathrm{~kg}$ of seeds. Fertilizations using liquid and granular N-P formulations were made in the sowing furrow, applying $272 \mathrm{~kg} \mathrm{ha}^{-1}$ of the formula 5-25-0 $\left(\mathrm{N}_{-} \mathrm{P}_{2} \mathrm{O}_{5}\right.$ $\mathrm{K}_{2} \mathrm{O}$ ). Potassium fertilization was topdressed immediately after sowing, using $48 \mathrm{~kg} \mathrm{ha}^{-1}$ of $\mathrm{K}_{2} \mathrm{O}$ in a granular source.

The plots were $2.25 \mathrm{~m}$ wide (5 sowing lines) and $5 \mathrm{~m}$ long. The useful area consisted of the three central lines, $4 \mathrm{~m}$ long. The base fertilization was carried out in the sowing furrow by a fertilizer sowing machine with five sowing lines spaced 0.45 $\mathrm{m}$ apart. For the distribution of the liquid fertilizer, dosers with flow register were used and for the granular fertilizer, helical dosers from the machine itself. The fertilizer sowing machine was regulated to operate at a speed of $4 \mathrm{~km} \mathrm{~h}^{-1}$ and to distribute 15 seeds of common bean, cultivar Pérola, per meter.

The experiments were installed in the first half of June of the two cropping years, in areas with slight differences in fertility, as shown in Table 1. The pivot-central sprinkler irrigation system was used, with water management as the requirement of the crop. Phytosanitary management was carried out according to crop needs (Vieira, Gomes, \& Figueira, 2006).

At the physiological maturation, in the phenological phase R9, plant density (PD) was determined in $2 \mathrm{~m}$ in the central row of each plot. Also, five plants were randomly collected per plot for evaluation of the number of pods per plant (NP), number of grains per pod (NG), mass of 100 grains (M100). Grain yield (GY) was determined by harvesting a useful area of $4.5 \mathrm{~m}^{2}$ in each plot, being expressed in $\mathrm{kg} \mathrm{ha}^{-1}$, with the values corrected to $13 \%$ moisture.

The data obtained in the experiments were grouped and the analysis by experiment group was performed. When the differences were significant, the results of each cropping year were analyzed separately, however, when there was no difference between the cropping years, the data were grouped. The data were submitted to analysis of variance and when confirming a statistically significant value in the $\mathrm{F}$ test $(\mathrm{p} \leq 0.05)$, mean values were compared by the " $t$ " test at $5 \%$ significance.

\section{Results and Discussion}

The evaluation of the effects of N-P formulations, the application depth of the N-P formulations and the inoculation with Rhizobium tropici in common bean revealed that the plant density (PD), the number of pods per plant (NP), and the grain yield (GY) did not differ between the evaluated cropping years (Table 2) and, therefore, the results obtained were analyzed together. While the number of grains (NG) and the mass of 100 grains (M100) differed between the evaluated cropping years, being analyzed separatelly (Table 2). 
Table 2

Joint analysis of the experiments carried out in the 2015 and 2016 cropping years, in the presence of topdressing

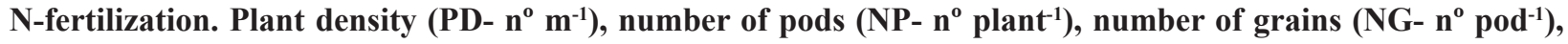
mass of 100 grains (M100- g) and grain yield (GY- $\mathrm{kg} \mathrm{ha}^{-1}$ ) of common bean

\begin{tabular}{lccccc}
\hline Cropping year $(\mathbf{C Y})$ & PD & NP & NG & M100 & GY \\
\hline $\mathbf{2 0 1 5}$ & 11.87 & 9.90 & $2.43 \mathrm{~B}$ & $24.04 \mathrm{~B}$ & 1.656 \\
$\mathbf{2 0 1 6}$ & 13.00 & 10.88 & $4.25 \mathrm{~A}$ & $25.95 \mathrm{~A}$ & 1.831 \\
$\boldsymbol{F}_{C Y}$ & $3.9^{n s}$ & $0.9^{n s}$ & $160.0^{* *}$ & $8.69^{*}$ & $5.4^{n s}$ \\
\hline $\mathbf{C V}(\%)$ & 12.7 & 25.4 & 15.2 & 8.1 & 22.4 \\
\hline
\end{tabular}

"significant ( $\mathrm{p} \leq 0.05$, " $\mathrm{F}$ " test), ${ }^{* *}$ significant ( $\mathrm{p} \leq 0.01$, " $\mathrm{F}$ " test), ${ }^{\text {ns }}$ non significant ( $\mathrm{p} \geq 0.05$, " $\mathrm{F}$ " test). Mean values followed by different letters within each column are statistically different ( $\mathrm{p} \leq 0.05$, teste " $\mathrm{t}$ ").

Neither liquid or granular N-P formulation affected PD, NP and GY. Also, N-P formulation did not interact with the other factorss (Table 3). However, the application depth of the N-P formulation affected in contrasting way PD and NP, showing greater PD at $12 \mathrm{~cm}$ depth and, greater NP at $6 \mathrm{~cm}$ depth (Table 3). Also, the inoculation with $R$. tropici improved the PD, increasing the GY (Table 3). According to Bertoldo, Pelisser, Silva, Favreto and Oliveira (2015), the seed inoculation with $R$. tropici provides better plant emergence, resulting in improved PD.

Table 3

Plant density (PD- $\mathbf{n}^{0} \mathrm{~m}^{-1}$ ), number of pods (NP- $\mathrm{n}^{0}$ plant $^{-1}$ ), and grain yield (GY- $\mathrm{kg} \mathrm{ha}^{-1}$ ) of the common bean as affected by the N-P formulation, application depth of the N-P formulation, and inoculation with Rhizobium tropici

\begin{tabular}{|c|c|c|c|}
\hline Factors & PD & $\mathbf{N P}$ & GY \\
\hline \multicolumn{4}{|l|}{ N-P formulation $(F)$} \\
\hline Liquid & 12.6 & 10.14 & $1,718.0$ \\
\hline Granular & 12.2 & 10.64 & $1,770.0$ \\
\hline$F_{F}$ & $1.01^{n s}$ & $0.6^{n s}$ & $0.29^{n s}$ \\
\hline \multicolumn{4}{|c|}{ Application depth (AD) } \\
\hline $6 \mathrm{~cm}$ & $11.9 \mathrm{~B}$ & $11.35 \mathrm{~A}$ & $1,697.0$ \\
\hline $12 \mathrm{~cm}$ & $13.0 \mathrm{~A}$ & $9.43 \mathrm{~B}$ & $1,791.0$ \\
\hline$F_{A D}$ & $8.24^{* *}$ & $8.44^{* *}$ & $0.95^{n s}$ \\
\hline \multicolumn{4}{|l|}{ Inoculation (I) } \\
\hline With $R$. tropici & $13.1 \mathrm{~A}$ & 11.0 & $1,851.0 \mathrm{~A}$ \\
\hline Without $R$. tropici & $11.7 \mathrm{~B}$ & 9.8 & $1,637.0 \mathrm{~B}$ \\
\hline$F_{I}$ & $12.05^{* *}$ & $3.43^{n s}$ & $4.91^{*}$ \\
\hline \multicolumn{4}{|l|}{ Interactions } \\
\hline$F_{F x A D}$ & $1.96^{n s}$ & $0.7^{n s}$ & $0.08^{n s}$ \\
\hline $\boldsymbol{F}_{F x I}$ & $0.54^{n s}$ & $0.28^{n s}$ & $0.43^{n s}$ \\
\hline$F_{A D x I}$ & $0.08^{n s}$ & $4.69^{*}$ & $8.56^{* *}$ \\
\hline$F_{F x A D x I}$ & $0.37^{n s}$ & $0.6^{n s}$ & $4.73^{*}$ \\
\hline $\mathrm{CV}(\%)$ & 12.7 & 25.4 & 22.4 \\
\hline
\end{tabular}

*significant ( $\mathrm{p} \leq 0.05$, " $\mathrm{F}$ " test), ${ }^{* *}$ significant $\left(\mathrm{p} \leq 0.01\right.$, " $\mathrm{F}$ " test), ${ }^{\mathrm{ns}}$ non significant $(\mathrm{p} \geq 0.05$, " $\mathrm{F}$ " test). Mean values followed by different letters within each column are statistically different ( $p \leq 0.05$, teste " $t$ "). 
Since no significative diferences were observed between liquid and granular N-P formulation for PD, NP, and GY, the formulation choose should be driven by other factors. Ease of handling and application, ease of blending, uniformity of application, and blend with crop protection products are some of the advantages of liquid fertilizer over granular formulation (Korndörfer, Anderson, Mundim, \& Simões, 1995; Desenvolvimento Rural, 2020). Also, compared to the granular formulation, the liquid formulation allows the application of the same concentration of nutrients in a smaller volume, allowing less energy consumption in the sowing operation and better homogeneity of the fertilizer components, which in the granular formulation are sparrows by the sower shaking (M. J. Silva, 2017). Thus, the choice of which type of formulation to use, granular or liquid, should be based on the costs, ease and convenience of application, as well as on the plant potential response.

Regarding the application depth of the N-P formulation, application in greater depth could provide greater root development, reflecting positively on the GY of the common bean. However, due to the common bean having a superficial root system (Vieira et al., 2006) and, since the soil presented medium to high fertility in the superficial layer (Table 1) (D. M. G. Sousa \& Lobato, 2004), the demand for nutrients necessary for the full development of the crop may have been supplied by the soil. Other authors also did not find significant differences in crop development due to the fertilization depth (J. G. Silva, Kluthcouski, Di Stefano, \& Aidar, 1999; J. G. Silva \& Silveira, 2002; M. A. Sousa, Lima, Silva, \& Andrade, 2009). Thus, applying fertilizer more superficially results in less horse-power demand and, therefore, less fuel consumption. According to Machado, Lanças, Fiorese, Fernandes and Testa (2015), superficial furrow opening operation results in less energy expenditure as compared to deeper furrow opening.

The application depth of the N-P formulations affected the NP and the GY, but the effect on the GY was dependent on the inoculation with $R$. tropici (Table 4). Interaction was observed between the inoculation with $R$. tropici and application depth factors, however, regardless of the application depth, inoculation with $R$. tropici increased GY in about $13 \%$. In the absence of $R$. tropici, the application of N-P formulation in greater depth favored GY.

\section{Table 4}

Number of pods (NP- $\mathbf{n}^{0}$ plant $\left.^{-1}\right)$ and grain yield (GY- $\mathrm{kg} \mathrm{ha}^{-1}$ ) as affected by the interaction between the application depth of the N-P formulation with the inoculation with Rhizobium tropici

\begin{tabular}{cccccc}
\hline \multirow{2}{*}{$\begin{array}{c}\text { Application } \\
\text { depth }\end{array}$} & with $\boldsymbol{R}$. tropici & without $\boldsymbol{R}$. tropici & & with $\boldsymbol{R}$. tropici & without $\boldsymbol{R}$. tropici \\
\cline { 2 - 3 } $\mathbf{6} \mathbf{~ c m}$ & $12.68 \mathrm{Aa}$ & $10.02 \mathrm{Ab}$ & & $1,945.0 \mathrm{Aa}$ & $1,448.0 \mathrm{Bb}$ \\
$\mathbf{1 2} \mathbf{~ c m}$ & $9.33 \mathrm{Ba}$ & $9.53 \mathrm{Aa}$ & & $1,757.0 \mathrm{Aa}$ & $1,825.0 \mathrm{Aa}$ \\
\hline Average & $11.01 \mathrm{~A}$ & $9.78 \mathrm{~A}$ & & $1,851.0 \mathrm{~A}$ & $1,636.5 \mathrm{~B}$ \\
\hline
\end{tabular}

Mean values followed by different lowercase letters in the line, and by different uppercase letters in the column, are statistically different ( $\mathrm{p} \leq 0.05$, teste “ $\mathrm{t}$ ”).

In the 2016 cropping year, the interaction between inoculation with $R$. tropici and application depth of N-P formulation positively influenced NP, by which greater NP was found with the inoculation with $R$. tropici and application of N-P formulation at $6 \mathrm{~cm}$ depth (Table 4). Similarly, GY was also affected by this interaction, where higher GY was found under the inoculation with $R$. tropici and application of $\mathrm{N}-\mathrm{P}$ formulation at $6 \mathrm{~cm}$ depth (Table 4). These results corroborate Moreira, Oliveira and Ferreira 
(2017), who reported that inoculation with $R$. tropici provides an improvement in yield components, such as $\mathrm{NG}$, reflecting in GY increasing. Additionally, as seen in table 3 , the GY of common bean inoculated with $R$. tropici was about $13 \%$ higher than that not inoculated, which represents an increase in GY by $214 \mathrm{~kg} \mathrm{ha}^{-1}$. Ferreira et al. (2000) reported that the use of inoculation can provide significant increases in productivity and cost reduction, due to the decrease in the need for nitrogen application. According to Gerlach, Arf, Corsini, Silva and Coletti (2013), the application of $90 \mathrm{~kg} \mathrm{ha}^{-1}$ of $\mathrm{N}$ represents $14 \%$ of the total operating cost. As rhizobial inoculant is a relatively inexpensive technology, this increase in productivity justifies the inoculation.
Differently of the other parameters, the effects of the treatments over NG and M100 varied between the cropping years. In both cropping years, NG and M100 were not affected by the evaluated factors neither its interactions, except the NG, which was affected in both cropping years by the interaction of the application depth of the N-P formulation and the inoculation with $R$. tropici, and by the interaction between the N-P formulation, application depth of the N-P formulation and the inoculation with $R$. tropici. Also, it was observed interaction between the N-P formulation, application depth of the N-P formulation and the inoculation with $R$. tropici for M100 in the 2016 cropping year (Table 5).

Table 5

Number of grains (NG- $\mathbf{n}^{0}$ pod $^{-1}$ ) and mass of 100 grains (M100- g) of the common bean as affected by the N-P formulation, application depth of the N-P formulation, and inoculation with Rhizobium tropici

\begin{tabular}{|c|c|c|c|c|}
\hline \multirow{2}{*}{ Factors } & \multicolumn{2}{|c|}{ NG } & \multicolumn{2}{|c|}{ M100 } \\
\hline & 2015 & 2016 & 2015 & 2016 \\
\hline \multicolumn{5}{|l|}{$N-P$ formulation $(F)$} \\
\hline Liquid & 2.4 & 4.3 & 25.6 & 23.7 \\
\hline Granular & 2.4 & 4.2 & 26.3 & 24.3 \\
\hline$F_{F}$ & $0.01^{n s}$ & $0.02^{n s}$ & $1.57^{n s}$ & $0.42^{n s}$ \\
\hline \multicolumn{5}{|c|}{ Application depth (AD) } \\
\hline $6 \mathrm{~cm}$ & 2.5 & 4.2 & 25.4 & 24.5 \\
\hline $12 \mathrm{~cm}$ & 2.4 & 4.3 & 26.5 & 23.6 \\
\hline$F_{A D}$ & $1.11^{n s}$ & $0.28^{n s}$ & $3.68^{n s}$ & $0.19^{n s}$ \\
\hline \multicolumn{5}{|l|}{ Inoculation (I) } \\
\hline With $R$. tropici & 2.4 & 4.0 & 25.8 & 23.5 \\
\hline Without $R$. tropici & 2.4 & 4.5 & 26.11 & 24.6 \\
\hline$F_{I}$ & $0.15^{n s}$ & $3.53^{n s}$ & $0.34^{n s}$ & $0.13^{n s}$ \\
\hline \multicolumn{5}{|l|}{ Interactions } \\
\hline$F_{F x A D}$ & $4.06^{n s}$ & $0.96^{n s}$ & $0.34^{n s}$ & $0.81^{n s}$ \\
\hline $\boldsymbol{F}_{F x I}$ & $0.92^{n s}$ & $0.96^{n s}$ & $3.01^{n s}$ & $0.39^{n s}$ \\
\hline$F_{A D x I}$ & $11.92^{* *}$ & $6.8^{*}$ & $1.05^{n s}$ & $0.31^{n s}$ \\
\hline$F_{F x A D x I}$ & $5.3^{*}$ & $0.23^{n s}$ & $5.02^{*}$ & $0.38^{n s}$ \\
\hline $\mathrm{CV}(\%)$ & 15.2 & 14.8 & 5.9 & 7.9 \\
\hline
\end{tabular}

*significant ( $\mathrm{p} \leq 0.05$, "F" test), ${ }^{* *}$ significant ( $\mathrm{p} \leq 0.01$, " $\mathrm{F}$ " test), ${ }^{\text {ns }}$ non significant $(\mathrm{p} \geq 0.05$, " $\mathrm{F}$ " test). Mean values followed by different letters within the column are statistically different ( $\mathrm{p} \leq 0.05$, teste " $\mathrm{t}$ "). 
In both cropping years, it was observed interaction between the application depth of the N-P formulation and the inoculation with $R$. tropici for the NG; however, without consistency of the results, which were quite divergent across cropping years (Table 6). In 2015, greater NG was observed when the seeds were inoculated with $R$. tropici and the $\mathrm{N}-\mathrm{P}$ formulation was applied at $6 \mathrm{~cm}$ depth, while in 2016 greater NG was observed without seeds inoculation with $R$. tropici and the N-P formulation was applied at $12 \mathrm{~cm}$ depth.

Table 6

Number of grains $\left(\mathrm{NG}-\mathrm{n}^{0} \operatorname{pod}^{-1}\right)$ in the 2015 and 2016 cropping years, as affected by the interaction between the application depth of the N-P formulation with the inoculation with $R$. tropici

\begin{tabular}{cccccc}
\hline \multirow{2}{*}{ Application depth } & \multicolumn{2}{c}{$\mathbf{2 0 1 5}$} & & \multicolumn{2}{c}{$\mathbf{2 0 1 6}$} \\
\cline { 2 - 3 } \cline { 5 - 6 } & with $\boldsymbol{R}$. tropici & without $\boldsymbol{R}$. tropici & & with $\boldsymbol{R}$. tropici & without $\boldsymbol{R}$. tropici \\
\hline $\mathbf{6} \mathbf{~ c m}$ & $2.7 \mathrm{Aa}$ & $2.2 \mathrm{Ab}$ & & $4.3 \mathrm{Aa}$ & $4.1 \mathrm{Ba}$ \\
$\mathbf{1 2} \mathbf{~ c m}$ & $2.2 \mathrm{Bb}$ & $2.6 \mathrm{Aa}$ & & $3.8 \mathrm{Ab}$ & $4.8 \mathrm{Aa}$ \\
\hline
\end{tabular}

Mean values followed by different lowercase letters in the line, and by different uppercase letters in the column, are statistically different ( $\mathrm{p} \leq 0.05$, teste “ $\mathrm{t}$ ”).

In spite of the good results of the inoculated treatments observed in our work, BNF in common bean is still a controversial issue. Some published papers show productivity ranging from 2500 to $3500 \mathrm{~kg} \mathrm{ha}^{-1}$ (Mostasso, Mostasso, Dias, Vargas, \& Hungria, 2002; Pelegrin, Mercante, Otsubo, \& Otsubo, 2009), while other the productivity varied from 600 to $1500 \mathrm{~kg} \mathrm{ha}^{-1}$ (Raposeiras et al., 2006; Souza, Soratto, \& Pagani, 2011; Valadão et al., 2009). Moreover, some authors state that the inoculation of common bean associated with a dose of $\mathrm{N}$ equivalent to $20 \mathrm{~kg} \mathrm{ha}^{-1}$ can provide productivity equivalent to the use of $80 \mathrm{~kg} \mathrm{ha}^{-1}$ of $\mathrm{N}$ (Soares et al., 2016) or $160 \mathrm{~kg} \mathrm{ha}^{-1}$ of $\mathrm{N}$ (Brito et al., 2011).

Although few studies have been carried out on the use of liquid fertilizer, our results indicate that the use of liquid N-P formulation, applied at $6 \mathrm{~cm}$ depth, associated with the inoculation with $R$. tropici, translates into advantages for the common bean producer, providing better control of application uniformity, minimal soil mobilization, less fuel consumption, among others, with the benefit of increased grain production.

\section{Conclusions}

As compared to the granular formulation the liquid N-P formulation provides similar results for all growth and grain yield parameters of the common bean.

The application depth of the N-P formulations affects the plant density and number of pods; however, does not affect grain yield.

Inoculation of the seed with $R$. tropici stimulates the yield components, increasing grain yield.

\section{References}

Alvares, C. A., Stape, J. L., Sentelhas, P. C., Gonçalves, J. L. M., \& Sparovek, G. (2013). Köppen's climate classification map for Brazil. Meteorologische Zeitschrift, 22(6), 711-728. doi: 10.1127/09412948/2013/ 0507

Bertoldo, J. G., Pelisser, A., Silva, R. P., Favreto, R., \& Oliveira, L. A. D. (2015). Alternatives in bean fertilization to reduce the application of $\mathrm{N}$-urea. Pesquisa Agropecuária Tropical, 45(3), 348-355. doi: 10.1590/1983-40632015v4534885 
Bortolotto, R. P., Bruno, I. P., Reichardt, K., Timm, L. C., Amado, T. J. C., \& Ferreira, A. O. (2012). Nitrogen fertilizer $\left({ }^{15} \mathrm{~N}\right)$ leaching in a central pivot fertigated coffee crop. Revista Ceres, 59(4), 466-475. doi: 10.1590/S0034-737X2012000400006

Brito, M. M. P., Muraoka, T., \& Silva, E. C. (2011). Contribuition of nitrogen from biological nitrogen fixation, nitrogen fertilizer and soil nitrogen on the growth of the common bean and cowpea. Bragantia, 70(1), 206-215. doi: 10.1590/S000687052011000100027

Compania Nacional de Abastecimento (2019). Acompanhamento da safra brasileira de grãos. Brasília: CONAB.

Desenvolvimento Rural (2020). Fertilizante granulado ou líquido. Recuperado de http:// desenvolvimento rural.com/fertilizantes-granulado-ou-liquido/

Donagena, G. K., Campo, D. V. B., Calderano, S. B., Teixeira, W. G., \& Viana, J. H. M. (2011). Manual de métodos de análise de solo (2a ed.). Rio de Janeiro: EMBRAPA Solos.

Ferreira, A. N., Arf, O., Carvalho, M. A. C., Araújo, R. S., Sá, M. E., \& Buzetti, S. (2000). Rhizobium tropici strains for inoculation of the common bean. Scientia Agricola, 57(3), 507-512. doi: 10.1590/S010390162000000300021

Gerlach, G. A. X., Arf, O., Corsini, D. C. D. C., Silva, J. C., \& Coletti, A. J. (2013) Economic analysis of bean yield according to nitrogen levels and cover crops. Pesquisa Agropecuária Tropical, 43(1), 42-49. doi: 10.1590/S1983-40632013000100005

Korndörfer, G. H., Anderson, D. L., Mundim, V. C., \& Simões, M. S. (1995). Liquid fertilizer production for sugarcane. Revista STAB, 14(2), 25-29.

Machado, T. M., Lanças, K. P., Fiorese, D. A., Fernandes, B. B., \& Testa, J. V. P. (2015). Estimativa de gasto energético da operação de subsolagem em profundidades variáveis. Revista Brasileira de Engenharia Agrícola e Ambiental, 19(11), 1121-1125. doi: 10.1590/1807-1929/agriambi. v19n11p1121-1125

Melém, N. J., Jr., Brito, O. R., Fonseca, N. S., Jr., Fonseca, I. C. B., \& Aguiar, S. X. (2011). Mineral nutrition and production of beans in areas managed with and without burning of organic residues and different fertilization types. Semina: Ciências Agrárias, 32(1), 7-18. doi: 10.5433/1679-0359.2011v32 n1 p7

Moreira, L. P., Oliveira, A. P. S., \& Ferreira, E. P. B. (2017). Nodulation, contribution of biological N2 fixation, and productivity of the common bean
(Phaseolus vulgaris L.) inoculated with rhizobia isolates. Australian Journal of Crop Science, 11(6), 644-651. doi: 10.21475/ajcs.17.11.06.p310

Mostasso, L., Mostasso, F. L., Dias, B. G., Vargas, M. A. T., \& Hungria, M. (2002). Selection of bean (Phaseulous vulgaris L.) rhizobial strains for the Brazilian Cerrados. Field Crops Research, 73(2-3), 121-132. doi: 10.1016/S0378-4290(01)00186-1

Nascente, A. S., Kluthcouski, J., Crusciol, C. A. C., Cobucci, T., \& Oliveira, P. (2012). Fertilization of common bean cultivars in tropical lowlands. Pesquisa Agropecuária Tropical, 42(4), 407-415. doi: 10. 1590/S1983-40632012000400003

Oliveira, A. P., Silva, V. R. F., Arruda, F. P., Nascimento, I. S., \& Alves, A. U. (2003). Rendimentos de feijão caupi em função de doses e formas de aplicação de nitrogênio. Horticultura Brasilera, 21(1), 77-80. doi: $10.1590 /$ S0102-05362003000100016

Pelegrin, R., Mercante, F. M., Otsubo, I. M. N., \& Otsubo, A. A. (2009). Response of common bean crop to nitrogen fertilization and rhizobium inoculation. Revista Brasileira de Ciência do Solo, 33(1), 219226. doi: 10.1590/S0100-06832009000100023

Raposeiras, R., Marriel, I. E., Muzzi, M. R. S., Paiva, E., Pereira, I. A., Fo., Carvalhais, L. C.,... Sá, N. M. H. (2006). Rhizobium strains competitiveness on bean nodulation in Cerrado soils. Pesquisa Agropecuária Brasileira, 41(3), 439-447. doi: 10.1590/S0100204X2006000300010

Rodrigues, R. A. R., Mello, W. Z., Conceição, M. C. G., Souza, P. A., \& Silva, J. J. N. (2017). Nitrogen dynamics in tropical agricultural and forest systems and their impact on climate change. Revista Virtual de Química, 9(5), 1868-1886. doi: 10.21577/19846835.20170110

Silva, J. G., \& Silveira, P. M. (2002). Avaliação de uma semeadora adubadora na cultura do milho. Santo Antonio de Goiás: EMBRAPA Arroz e Feijão.

Silva, J. G., Kluthcouski, J., Di Stefano, J. G., \& Aidar, H. (1999). Efeitos da velocidade de operação e da profundidade de adubação de uma semeadora adubadora no estabelecimento e na produtividade da cultura do feijoeiro sob plantio direto. In $\mathrm{T}$. Cobucci (Ed.), Avanços tecnológicos com a cultura do feijoeiro comum no sistema de plantio direto (pp. 21-25). Santo Antônio de Goiás: EMBRAPA Arroz e Feijão.

Silva, M. J. (2017). Processo para aplicação localizada de fertilizante líquido nitrogenado em cana-soca. Campinas: UNICAMP. 
Siqueira, M., Neto, Piccoli, M. C., Costa, C., Jr., Cerri, C. C., \& Bernoux, M. (2011). Greenhouse gas emission caused by different land-uses in brazilian Savannah. Revista Brasileira de Ciência do Solo, 35(1), 63-76. doi: 10.1590/S0100-06832011000100006

Soares, B. L., Ferreira, P. A. A., Rufini, M., Martins, F. A. D., Oliveira, D. P., Reis, R. P.,... Moreira, F. M. S. (2016). Agronomic and economic efficiency of common-bean inoculation with rhizobia and mineral nitrogen fertilization. Revista Brasileira de Ciencia do Solo, 40(1), 1-13. doi: 10.1590/18069657rbcs 20150235

Sousa, D. M. G., \& Lobato, E. (2004). Cerrado: correção do solo e adubação. Brasília: EMBRAPA Informação Tecnológica.

Sousa, M. A., Lima, M. D. B., Silva, M. V. V., \& Andrade, J. W. S. (2009) Water stress and fertilizer incorporation depth affecting bean yield components. Pesquisa Agropecuária Tropical, 39(2), 175-182.
Souza, E. F. C., Soratto, R. P., \& Pagani, F. A. (2011) Nitrogen fertilization and rhizobium inoculation in common bean cultivated after corn intercropped with palisade grass. Pesquisa Agropecuária Brasileira, 46(4), 370-377. doi: 10.1590/S0100204X2011000400005

Valadão, F. C. A., Jakelaitis, A., Conus, L. A., Borchartt, L., Oliveira, A. A., \& Valadão, D. D., Jr. (2009). Seeds inoculation and nitrogen and molybdenum fertilization of common bean in Rolim de Moura, RO. Acta Amazônica, 39(4), 741-748. doi: 10.1590/ S0044-59672009000400002

Vieira, M. R., Gomes, E. C., \& Figueira, J. C. (2006). Chemical control of Calacarus heveae feres (Acari: Eriophyidae) on rubber tree. Bioassay, 1(9), 1-7. doi: 10.14295/BA.v1.0.37

Vincent, J. M. (1970). A manual for the practical study of root nodule bacteria. Berkshire, England: International Biological Programme Handbook 15. 